\title{
Help of neutral countries in the return to life of the Women deportees from Ravensbrück camp. The Spanish Women case
}

\author{
Rose Duroux \\ Université Clermont Auvergne \\ e-mail : rose.duroux@orange.fr \\ ORCID iD: https://orcid.org/0000-0001-9282-9040
}

Submitted: 18 May 2018. Accepted: 2 April 2019

\begin{abstract}
Nothing more usual than to find Spanish refugees of 1939 in the French Resistance as they continued their fight against fascism. Therefore, hundreds of Spaniards where caught in the nets of the Vichy Government and the Gestapo. They are imprisoned in the French jails (Toulouse, Montluc, Fresnes, Compiègne, etc.) alongside the French Resistant women. Both will be piled up in wagons to the camps of the Third Reich. Many ended at the women's camp in Ravensbrück. Usually, the Spaniards were labelled "F", "French", because they were arrested in France. This "F" was part of the "red triangle" of the "political prisoners". Some were even classified NN (Nacht und $\mathrm{Nebel}$ ), i.e. called to disappear without a trace. As they were recognized by nobody (neither the French nor the Spaniards), this means: no mail, no parcels. They held on for life thanks to the links they forged randomly across blocks, satellite camps, languages, affinities... However, many died. For some of them, the release arrived in April 1944, thanks to "neutral" countries initiatives: in fact, a few Spanish women were able to slip into the Red Cross convoys transiting through Switzerland, which were initially reserved for French women. Others returned by Sweden. Others, finally, faced the apocalyptic evacuation of the camps of 1945 and the "marches of death". We propose to study "the return to life" helps through some cases - obviously return to France since there could be no possible repatriation for these Spanish anti-fascist survivors, as the victory of the Allies did not affect General Franco's power. After returning to France, this help continued for two or three years, in particular thanks to convalescent stays in Switzerland, Sweden and somewhere else, and thanks to one-off material contributions from the Swiss Grant ("Don suisse") or from various organizations.
\end{abstract}

KEYWORDS: 1939-1945; Spanish refugees; Women's camp; Return; Swiss rescue; Swedish rescue.

Citation / Cómo citar este artículo: Duroux, Rose (2019) "Help of neutral countries in the return to life of the Women deportees from Ravensbrück camp. The Spanish Women case". Culture \& History Digital Journal, 8 (2): e24. https://doi. org/10.3989/chdj.2019.024

RESUMEN: La ayuda de los países neutrales en el retorno a la vida de las mujeres rescatadas del campo de Ravensbrück. El caso de las mujeres españolas. Que se hallen refugiadas de 1939 en la Resistencia francesa, nada más natural: prosiguen su lucha contra el fascismo. Se cuentan por centenas las españolas atrapadas en las redadas "vichystas" y "gestapistas". Las encarcelan con las resistentes francesas en las cárceles de Francia (Toulouse, Montluc, Fresnes, Compiègne, etc.), las hacinan en vagones destinados a los campos del III Reich. Muchas van a parar al campo de mujeres de Ravensbrück. Las españolas son catalogadas "F", "francesas", por haber sido detenidas en Francia. Esa "F" se inscribe en el "triángulo rojo" de las "políticas". A algunas las clasifican "NN" (Nacht und Nebel), es decir llamadas a desaparecer sin dejar rastro. No ser reconocidas ni por el Estado francés, ni por el Estado español, eso significa: ni cartas, ni paquetes. Lo que les permitió resistir fueron los lazos que (se) tejieron al azar de los bloques, de los campos satélites, de los idiomas, de las afinidades... Pero muchas murieron. Para algunas la liberación llegó en abril de 1945, gracias a iniciativas de países neutrales. Unas cuantas pudieron deslizarse en los convoyes de la Cruz Roja reservados a las francesas que transitaron por Suiza. Otras volvieron por Suecia. Otras, por fin, sufrieron la evacuación apocalíptica de los campos de 1945 y las "marchas de la muerte". Se estudiarán las ayudas al 
"retorno a la vida" a través de algunos casos -retorno a Francia ya que era imposible repatriar a España a esas supervivientes antifascistas, la victoria de los Aliados no habiendo afectado en nada el poder del general Franco. Aquellas ayudas se prologaron después de la liberación durante dos o tres años, en particular mediante estancias de convalecencia en Suiza y en Suecia, y aportes (materiales) procedentes del "Don Suisse" o de otros organismos.

PALABRAS CLAVE: 1939-1945; Refugiadas españolas; Campo de mujeres; retorno; Ayuda suiza; Ayuda sueca.

Copyright: (C) 2019 CSIC. This is an open-access article distributed under the terms of the Creative Commons Attribution 4.0 International (CC BY 4.0) License.

We would return. We would tell the story.

Later. For the time being, it was a question of regaining strength, of recovering one's own life, the one of before or the start of a new life.

Charlotte Delbo

\section{PREAMBLE: OF THE INVISIBILITY OF SPANISH DEPORTED WOMEN}

My purpose is to trace the rescue of a few hundred female deportees of the women's camp of Ravensbrück (Northern Berlin) by humanitarian organizations of neutral countries during the particularly deadly weeks which preceded the fall of the III $^{\text {rd }}$ Reich. This story describes the rescue of the first deported woman who were liberated from the concentration camps between April 1945 and 1947, following the deceleration of transnational funds. Amongst these hundreds of women, I will attempt to highlight as far as possible the rescue of Spanish women who were arrested in France between 1942 and 1944 for their involvement in the Resistance.

The number of female deportees of Ravensbrück and its workplace satellites sites called Kommandos is estimated around 130000. According to the study of Jacqueline Fleury and Marie-Suzanne Binetruy (1995), the French women represented $8 \%$ of the camp population. On top of the list were the Polish women with $36 \%$, the Soviet women, $21 \%$, the German and the Austrian women, $18 \%$.

The number of French women in Ravensbrück is generally estimated at 8000 , an estimate which included Spanish women whose supporting friendship association has now estimated at 400 , which comprises $5 \%$ of the French contingent. ${ }^{1}$

The Spanish refugees "arrested in France and speaking French", affirmed Germaine Tillion, "were mixed in the mass of the French women and did not react differently". From this point on, she would no longer make a distinction between them.

When I started this research about the "return to normal life" (a topic on which there is an extensive bibliography ${ }^{2}$ ), I did not know how much I would have to face the invisibility of my object of study and how I would struggle to identify these "immigrant women" arrested in France between 1942 and 1944, because of the Resistance, and who were often Republicans of the Spanish War in exile, but not all of them.

Several reasons can explain this difficulty in identifying the Spanish women who passed by Ravensbrück: on the one hand, the Germans, who arrested these women in France and apprehended them as French. On the other hand, the French deportees themselves, like Germaine Tillion says, encompassed them in the French groups. Moreover, their names were usually gallicized (Neus can become Neige), and in the Camp only the first name was known, as indicated in the first issue of Voix et Visages (Voices and Faces), the bulletin created by the Association of deportees and prisoners of The Resistance, referring to the "emaciated faces of Ravensbrück, that only the first name identified"3. What is more, the active resistants usually used an alias: indeed who would recognize Virtudes Cuevas, spouse Codina, in her alias "Madame Carmen" and "Madame Vidal"4, or Mercedes Nuñez, single, arrested as "Francisca Puig, born Colomer", and nicknamed "Paquita".

The emblematic example of this presence-absence was given to me by the Nuremberg Process. At the hearing of January 28, 19465 , Marie-Claude Vaillant-Couturier reported the "Martyrdom" of Leonor Rubiano, born Spanish in Asturias" ${ }^{6}$, referred as to "my dear friend Marie" For Marie-Claude Vaillant-Couturier "Marie Rubiano" is French in her own right. A few lines of her declaration is proof of this.

"So, 600 women worked for 12 hours without any ventilation. All those who worked at the Schneiderei became skeletal at the end of a few months, began to cough, their eyesight deteriorated, they had nervous tics, caused by the fear of being hit. I know well the conditions of this workshop, because my dear friend Marie Rubiano, a French girl who had just spent three years in Kottbus prison, arrived in Ravensbrück and was sent to the Schneiderei and each evening she would tell me her martyrdom... Dr. Winkelmann, the specialist of the selections in Ravensbrück wrote down her name on his black list and on $9^{\text {th }}$ of February 1945, with 72 other tuberculosis patients, including 6 French women, she was hoisted into the truck for the gas chamber."

The archives of three associations of the former Ravensbrück female deportees would help me in identifying the Spanish women: ADIR (1945), an acronym of the Association of Deportees jailed during Resistance already quoted as The Amicale of Ravensbrück and its Kommandos (1947) and the international committee of Ravensbrück (1996). However, for the two years immediately after the war that this work focuses on, I had to give special importance to the ADIR which was created in the 
early 1945 and supported by its liaison bulletin, Voix et Visages, whose title expresses the will to be audible and visible (De Gaulle-Anthonioz: 1977; Mezzasalma: 2003; Pavillard: 2008). Twenty years later, the ADIR and the French friendly group Amicale de Ravensbrück (Amicale de Ravensbrück and ADIR, 1965) -which the Cold War had suspended (Chombart de Lauwe 1998: 192)- would publish together Les Françaises à Ravensbrück (1965) an admirable book of testimonies, but one which Montserrat Roig (1977) deplored as containing only four lines on the Spanish women.

It was not until the 1970s that the Spanish women who survived -Conchita Boix, Lola Casadellà, Neus Català, Marí González et Carmen Ramos- began the general count. In 1977 followed the study of Montserrat Roig Els catalans als camps nazis. Curiously, it is at the moment when the ADIR dismantles ${ }^{8}$, in 2005, on its 60th anniversary (the number of contributors diminishing irredeemably), that the Amical de Ravensbrück ${ }^{9}$ was officially created in Spain, relayed it is true by the academics of Barcelona like Mar Trallero. At present, this Amical has recorded, and sometimes biographed, 119 Spanish women and established a subsidiary list of 21 deportees.

It seemed necessary to explain further, as an introduction, the difficulty of identifying the group under observation - before going into the heart of the matter, in other words, the role of neutral countries in the liberation of deportees and the human-sanitary follow-up of the operation between 1945 and 1947. Only the anticipated evacuations will be discussed, that is to say, the ones before the liberation of the Camps by the Russians or the allies, sometimes lasting only a few days, but deadly days (Laffitte; Bourgeois: 2009). ${ }^{10}$ Nevertheless, to begin, this study will focus on the help of Switzerland then followed by that of Sweden.

\section{HUMANITARIAN GESTURES FROM SWITZERLAND}

For the first part of this review, I will refer to the work of Sébastien Farré11, who measured and problematized the Swiss aid of the time: it shows that the intervention carried out by the Swiss in favour of the deportees occupied "a secondary place compared with the one developed for prisoners of war" (2012: 201) and this, following Jean-Claude Favez (1988; 1989), who described this intervention as humanitarian gestures. Two of these gestures concern the French women who passed through Ravensbrück: First, the liberation in April 1945 of three hundred deported women by the International Committee of the Red Cross. After the survivors were repatriated, their convalescence care was covered by the "Swiss Gift for Victims of War" created in 1944 at the initiative of the Federal Council and financed by public and private organizations. Jean-Claude Favez (1988: 391) emphasizes the pressure exerted by the Allies on neutral countries (and also on the Vatican) in order to make "a supreme step with the German authorities to obtain the release of civilian, political or racial detainees". On this ground, the
Swiss diplomacy prefers to hand over the responsibility to the International Committee of the Red Cross. It is in this context that the Allies grant the Committee the means of intervention (foodstuffs, a fleet of trucks) and that rescue operations are undertaken. ${ }^{12}$ Swiss delegates recruited in an emergency were sent to the field almost without preparation (Farré underlined the perilous compassionate initiatives in the midst of the final chaos).

\section{Repatriations}

Nevertheless, the last weeks of the conflict allowed Geneva to carry out several evacuations of French deportees brought in by the frontier towns of Kreuzlingen, on the German-Swiss border, and St. Gallen, on the Austrian-Swiss border.

\section{First: Kreuzlingen}

The first truckload (5 April 945) from Ravensbrück to Switzerland of 300 officially French detainees constituted the counterpart for the release in France of 454 Germans (Farré 2012: 209-210) ${ }^{13}$. The convoy arrived on $9^{\text {th }}$ April in Kreuzlingen. Some returnees were hospitalized. The appearance of the survivors was so disastrous that the Red Cross decided to keep them a day. The authorities feared that the temporary base would become a long term stay (Favez: 397). The train took them from Kreuzlingen to Annemasse where they arrive on 11 April. On 14 April. General de Gaulle welcomed them to the Gare de Lyon ${ }^{14}$, from where they were directed to the Hotel Lutetia, which had become a reception center.

It was necessary to cross-check to identify the Spanish women among these ghosts whose numbered list (exceptionally exhaustive) bore numbers followed by names:

- $\mathrm{N}^{\circ} 18$ "Dupuy Demetria". As it turns out she was Basque, born on $22^{\text {nd }}$ December 1907 in Mués (Navarra); Mrs. Gaston Ganuza;

- N$^{\circ} 274$ "Fludia Rosa" was actually Roser Fluvià, Catalan;

- $\mathrm{N}^{\circ} 147$ "Kerwich Laure". This was Laura Gallart Marquès, born Catalan on $2^{\text {nd }}$ December 1896 in Palafrugell (Girona). Like Geneviève de Gaulle, she had been part of the convoy of " 27000 " $(27181)^{15}$, who had left the camp of Compiègne on 31 January 1944 with 959 detainees.

Three out of three hundred: this is below the aforementioned representation threshold (5\%). The Ravensbrück concentration camp was liberated by the Russian army on 30 April 1945.

\section{Second: St. Gallen}

The organization of a new convoy to Ravensbrück was hindered by the impracticability of roads between northern and southern Germany. The ICRC's action would then move south, in this case to Austria and the Mauthausen 
concentration camp. We would find there the women of "NN" (Nacht und Nebel) of Ravensbrück transferred on 2 March 1945 to Mauthausen with the Gypsies (Tillion 1973: 130) $)^{16}$-who were especially persecuted-, thus making matters more serious. The "NN" were, as we know, destined to disappear in the "night and the fog (They were forbidden parcels, mail and work outside the camp). Amongst the "NN" there were Spanish women.

The International Committee of the Red Cross carried out three transports of deportees from Mauthausen, which transported 780 deportees of French, Belgian, Luxemburg and Dutch nationality. The departure from Mauthausen, 22 April 1945, was done in 3 groups. There were the thirty officially French "NN", amongst them, Denise Vernay, sister of Simone Veil. We shall see farther on that some Spanish women were part of it. A few days later, two new convoys ensured the successive evacuation of 183 then of 349 deportees from Mauthausen (Farré 2012: 210). ${ }^{17}$

In the testimonies of the Spanish women, the evacuation by truck on 22 April 1945 offers little detail. I therefore refer to the testimony of Mari-Jo Chombart de Lauwe in Les Françaises à Ravensbrück (1965: 273-274). Her mother was in the first group of trucks; she was in the third. She tells, on 22 April 1945: "Finally, the door of the camp opens, white trucks, under the sign of the Red Cross, come to us and we leave. [...] Our convoy is escorted by Germans. It's still war. [...] We drive three days through Austria".

Arrival in St. Gallen on 24 April.

"A few days later, after having passed medical tests, the ablest will arrive in Paris on 30 April." Violette Maurice also remembers the arrival in St. Gallen on 24 April "We were kept for a few days in St. Gallen to avoid the risks and to be fed gradually. Beforehand, an incident at the border had shown us the fragility of our lot... ${ }^{18}$

The Swiss delegate Rubli is frankly critical of the border' incident. The case was noted by Farré (2012: 217): "In his report, on his return from Mauthausen, Delegate Rubli complains bitterly of the conditions of reception of the evacuees in Switzerland, which he considers 'disgraceful'". Column 36 (the one where Chombart de Lauwe is), and for which Rubli takes responsibility, is blocked on 23 April at the border by the Swiss customs authorities. "Ex-prisoners are forced to spend the night on the road, without blankets, hot drinks or food." Rubli also points out "the absence of sanitary facilities, shelters and the transfer of evacuees in third-class cars".

In the testimony of Chombart de Lauwe (1998: 155$156)$, it is not the Swiss who are in question but the Germans:

"Finally, when we reached the end, night had already fallen. The border was closed, the Germans refused to let us enter Switzerland. Himmler came back on his promise to free us. Throughout the night, the trucks remained behind the crossing while the convoy leaders tried to extract a permission from the Germans. We were in anguish; Rather than return to where we came from, we preferred to fight, revolt and die here.
Finally, in the morning, the barriers rose, and when the last of the thirteen cars was on Swiss soil, sobbing, we sang an extraordinary Marseillaise, which made the Swiss themselves cry. We sang while driving to St. Gall where we met our comrades and Mom."

We would tend to believe the Swiss delegate and follow Sebastien Farré, who had tried to show the difficulties of the delegates hastily sent on the field.

On 28 April 1945, the ICRC's last early release transfer was completed ${ }^{19}$. The Mauthausen camp was liberated on 5 May by the American army (Farré 2012: 213-214).

What about the Spanish women? They were present in the "NN" climbing on to the trucks of the Red Cross on 22 April 2015. I identified seven of them but this number is not exhaustive:

- Bueno Vela Alfonsina (wife of José Ester, who would leave in one of the convoys just like Arthur London, Czech). ${ }^{20}$

- Da Silva Rosita.

- García Carlota, known as "Charlie".

- Martínez Angelina/Ángeles who, according to Bermejo y Checa (2006), would be treated in a Swiss sanatorium..$^{21}$

- Martorell Herminia, born Rosales.

- Zapater Aguilera Carmen.

- Pintos Navas Feliciana, known as Mrs. Félicienne Bierge. ${ }^{22}$ Charlotte Delbo (1998: 41) included her as part of the " 31000 " (the series of tattooed women) passed by Auswichtz, from which she was the only Spanish survivor: “On 22 April 1945, Félicienne Bierge was one of the thirty for which the Red Cross was responsible, was transported by truck to St. Gallen. From this moment on, they reached Paris by train where they arrived on the 30 April."

In summary, the ICRC's contribution to the rescue of the deportees was "modest". Farré (2012: 219) does not hesitate to speak of "a tinkering line within an emergency". This inadequate assistance at this decisive turning point in the World War was a contribution with no possible comparison with that of the assistance to war prisoners. This latter contribution was intelligently organized and administered, as regards assistance and information, an organization which had already proven itself during the First World War (with reference to Farré work of 2014 on the War Parcels).

\section{Convalescence in Switzerland}

As for the survivors, the physical and psychological scars threatened to last, so the ADIR provided nursing homes in French-speaking Switzerland, nine houses in all. The first opened in July 1945 and the last closed in March 1947 (Monnier and Exchaquet-Monnier: 2013). They were located in Crassier, Nyon, Mont-sur-Lausanne, Les Avants-sur-Montreux, Château d'Ex, Villarssur-Ollon, Grand Champ, Freiburg and Montana. ${ }^{23}$ 
This initiative was instigated by Geneviève de Gaulle, and its execution was at the start the result of the testimonials of the survivors, especially their conferences -some illustrated by their drawings made in the camp- and also of the investment of the French colony in Switzerland. For the rest, Swiss private associations provided about half of the funding; the other half was provided by the Don Suisse, which devoted a very small part of its budget to it, but it succeeds in making a humanitarian gesture and a good showcase for the Swiss population. The survivors arrived from Paris by convoys, after selection by the $\mathrm{ADIR}^{24}$, on medical recommendation. They came from different regions and backgrounds. They are mainly resistant workers deported to Ravensbrück but there were also some Jewish women deportees.

The Voix et Visages bulletin concluded at the end of 1946: "We have nine convalescent homes in Switzerland, where more than 500 comrades have spent two to four months. The GA of December 1946 was confident: "We were able to maintain these houses thanks to the grants of the Don Suisse and thanks to the special donations. All these combined efforts produced excellent results from January to September." ${ }^{25}$ However, these convalescences presupposed a "big effort" for the Association. That is why Voix et Visages expressed sincere thanks "to the SOS committee in Lausanne and to the directors of convalescent homes". ${ }^{26}$

At the beginning of 1948, the tone changed: the ADIR bulletin deplored the end of convalescence, especially that of tuberculosis patients in Montana, and negotiated with the Don Suisse, to direct some patients to Leysin and Davos. ADIR concluded: "It is obviously a pity that we no longer have Swiss funds." 27

The book Retour à la vie (Return to life), by Éric Monnier and Brigitte Exchaquet-Monnier, the daughter of a doctor who took care of the patients in convalescence, describes the organization of each of these houses in detail. The authors were able, in most cases, to compile the list of deportees from house to house. This identification required detective work, such as a signature in a guestbook or on a tablecloth that could be the sign of the presence of a patient. The book was fed by direct and indirect testimonies (those of comrades or heirs) and showed how a convalescence was formed that combined medical care, collective activities, exchanges with the inhabitants of the villages, trips to in Lausanne. This is also the period during which Brigitte Exchaquet and Éric Monnier, and some convalescing deportees, such as Charlotte Delbo, Anise Postel-Vinay and Germaine Tillion, wrote their first analyses of the concentration camp experience.

To stay on course, I will consider the homes that received at least one Spanish woman. According to the summary table of the authors of Retour à la vie, these include:

- Pilar Lubian, received in Nyon at Villa-du-Port, between August and November 1945. Is she the former secretary of the Finance Minister of Juan Neg- rín, Francisco Méndez Aspe? In Switzerland, she is Pilar Lubian. This mysterious and opaque Pilar (said Méndez or Gorbea, born in 1913 or 1916) was in the convoy of the "39000" party of Paris on 13 May 1944, according to the Foundation for the memory of the deportation.

The following three convalescents were in the convoy of the " 27000 " party of Compiègne on 31 January, 194 including Geneviève de Gaulle:

- Pérez J. was in Villars-sur-Ollon, at Chalet Rosemont, opened from October 1945 to September 1946. Would it be Rita Pérez, mentioned below?

- Roger Neige, born Català, would stay for four months at Mont-sur-Lausanne, at the Pension Hortensia, open from November 1945 to May 1946. She enchanted the residents with her soprano voice.

- Vidal Virtudes ("Carmen"), born Cuevas, was in Nyon at the Villa-du-Port.

Everyone was satisfied with the welcome of the Swiss, even if some were reluctant to be so perfectly supervised, as this little remark of the secretary of the ADIR in the September 1946 bulletin implies: "The deportees are still tormented which is not always easy to manage". ${ }^{28}$ There was even a discordant voice in the general satisfaction, that of a young girl, hardly twenty years old, who felt that she was living a supervised liberty: Simone Veil (Monnier: 75-76).

\section{HELP FROM SWEDEN}

Now, let's consider without further ado the aid of Sweden during the rescues of April 1945. At this time, the liberating crossings of the door of the camp of Ravensbrück would take place in the week of 23 to 28 April.

It was the Swedish Red Cross vice-president, Folke Bernadotte himself, who obtained the go-ahead, after a meeting with Himmler, the transport of 4700 Scandinavian detainees to Neuengamme pending their repatriation. At the end of April, with the participation of ICRC trucks, he organized the evacuation of 2900 women detained in Ravensbrück (Farré 2012: 205).

\footnotetext{
"Until the last minute, it was necessary for the representatives of the Swedish Red Cross to discuss with Suhren, the SS commander of Ravensbrück the permission to allow all the detainees to leave, in accordance with the agreement with the Swedish Red Cross". ${ }^{29}$
}

Let us reflect on the trajectory of the 600 French women -unless there has been an error, they were released from the camp of Ravensbrück by the Red Cross and conducted and cared for in Sweden before being repatriated. There were several columns of white buses, White Buses. The first convoy of sick women left Ravensbrück on 23 April 1945, after crossing Denmark, where they were treated and pampered, arrived in Malmö on the Swedish 
coast on 26 April. In this trip three infants were saved, born to a French mother who survived. It should be remembered that in Ravensbrück, between 1944 and 1945, there were only five survivors out of the 850 births. ${ }^{30}$

One of the evacuees ("the revenants") of the first convoy of liberation by the Swedish Red Cross, Germaine Tillion (1973: 80), a good ethnologist, created in situ "revised lists" and managed to identify 336 released people. ${ }^{31}$

The second transport left for Sweden on 25 April. On 28 April, a Red Cross car still managed to extract twentysix patients from the camp.

In northern Germany, Sweden was not without difficulty carrying out its repatriation work, Kommando by Kommando, saving the deportees in extremis. One thinks, for example, of the Kommandos of Bendorf, Neuengamme, Sasel or Ochzensol. ${ }^{32}$

It should be emphasized that all returnees by the White Buses had a medical stay of two to three months or more. The deportees were housed in various centers (Trelleborg, Ryd, Göteborg, Malmö) and received first aid. Communal rooms and schools were transformed into hospices. Volunteer nurses served exhausted women and gave survivors psychological support. Some of them recall the "incredible generosity of Senator Branting" (Gelly: 2013). The Press highlighted this. The civilian population readily offered shelter and food.

A French legation photographed each of them to create identity papers. Their list was broadcast on French radio and published in one of the dailies.

\begin{abstract}
"Mid-June, airplane repatriations were organized. Every two days or so, fifteen to twenty women landed at Le Bourget before joining the Hotel Lutetia by bus. The last women returned in October. After several weeks of convalescence in Sweden, these deportees returned to their country in better condition than the other returnees." (Dufayel: 2015)
\end{abstract}

All the survivors had experienced a highly human Swedish welcome. Odette Fabius (1986: 209) simply summarizes this feeling experienced by the women who came back from Sweden: "We were admirably received, fed, pampered, spoilt."

There were also returns by boat, as Claude Bloch testifies:

"So we spent two months in Sweden. We were well
cared for. Then we were taken to a mountain hotel. And
on 14 July, we were reembarked on a line steamer in
Gothenburg, round the British Isles, as the Pas-de-Cal-
ais was mined. We landed in Cherbourg on 20 July. And
after the usual checks, we were brought back to Paris." 33

Amongst the "French" returnees, one can include, some Spanish women; I could identify only four in the first convoy to Sweden where they spent a few months: María Beguiristain, born Guesalaga ${ }^{34}$; Amanda García, known as Carmen Lafuente; Rita Pérez; Elisa Masallès, born Ruiz, also known as Elisa Ruiz Garrido, passed by the Kommando of Leipzig. Care was taken not to repatriate them to the Francoist Spain (which, moreover, would not have wanted it).

It would be interesting to see what the ambassadors of Spain in Stockholm or Paris wrote to their Minister at that time.

\section{Continuation of Scandinavian aid in the immediate post-war period}

During the following two years, Sweden and Denmark would not forget their evacuees either. Contacts were maintained and even a Swedish family offered to shelter a child. ${ }^{35}$ Voix et Visages portrayed the three voyages offered in 1946-1947 by Denmark and Sweden to twenty deportees received in families. ${ }^{36}$ I do not know, at present, whether there was a Spanish woman amongst them. What is certain is that the gratitude of the survivors of Ravensbrück is palpable and durable; For example, its concrete and symbolic expression was evident in a firstclass tablecloth offered to Count Bernadotte by the deportees who had returned from Sweden: "This tablecloth carries a tricoloured bouquet in the centre and, on the edge, between Swedish colours, the names of the comrades saved by the intervention of Count Bernadotte." ${ }^{37}$

In short: Jean-Claude Favez and Sébastien Farré were not wrong when they pointed out that the ICRC's intervention for the liberation and rescue of women from Ravensbrück remained, rightly or wrongly, in the shadows of the one led by Bernadotte.

\section{Another note}

We will not delve into the punctual aid that the deportees were able to receive in France from 1945 to 1947 (such as the sending of furniture or medicines by the Don Suisse). ${ }^{38}$ On their return, deportees -including Spanish women- were able to benefit unequally from aid of national, regional, municipal, associative or humanitarian organizations, in particular the American "Committee" of mutual assistance: American Friends Service, American Joint Antifascist or the Unitarian Service ${ }^{39}$; The latter would deserve more than the three lines which I devote to them here; Their "Home" in Meillon attached to the Warsaw Hospital in Toulouse opened its doors to the Spanish victims of the Nazis and received in 1947, amongst others, some old Ravensbrück survivors: María González, Mercedes Núñez, María Llenas, Isabel Ruiz, Neus Català, etc. ${ }^{40}$

\section{CONCLUSIONS}

We have seen that the fate of the Spanish women was inextricably linked to that of the deported women who were called the "Frenchwomen of Ravensbrück". But while some returned to their own country, the others were accepted into a land of exile. Certainly these Spanish women were no longer the "undesirables" of xenophobic France according to the decree on 12 November 1938 since the decree on $15^{\text {th }}$ March 1945 gave them the status 
of "political refugees" (without civil rights). One can imagine that the difficulties to overcome were more numerous for them; But the Spanish survivors would not write anything on this grey area. An example: this problematic stage of the "normalization" of life constituted only the short final paragraph in the book by Mercedes Núñez Targa, Destinada al crematorio (2011: 153). However, this author who at one time was Pablo Neruda's secretary and a fluid writer summarized in radically short terms, the many health and humanitarian aids (all in the plural) that allowed her return to physical and psychological normality: "Then there were long parentheses of sanatoria, hospitals, nursing homes, relapses and operating theaters. I have to overcome the fear of returning to normal life". ${ }^{41}$ Even then the author waited for the short concluding paragraph of her work to evoke this difficult return to life. We would not know, at least by her pen, that one of these "nursing homes" - to mention but one- was that of the Unitarian Service Committee of Meillon in the Pyrenees. Other stories of life can be found in the collection of fifty testimonies by Neus Català (1994), which deserves to be hailed for its fight against forgetting the deportation of Spanish women. ${ }^{42}$ Many deportees had died when Neus was preparing his collection of testimonies. It should be noted that, here again, the women witnesses are very discreet, even silent, on their life' relearning.

Diction, omission, fiction, silence. For Marcelle Soulier, of Clermont-Ferrand, there is no communal experience of returning to life, "each having had her way of exorcising the past".

The historiography of the deportation of the Spanish women is slow to come. The 5000 Spanish women who died at the Mauthausen concentration camp have rightly monopolized our attention. ${ }^{43}$ But, in the last analysis, it seems that the light projected on Mauthausen ended up reflecting on the Spanish women of Ravensbrück.

\section{ACKNOWLEDGMENTS}

This article forms part of the project "European $\mathrm{Hu}$ manitarian Aid in France during the Second World War". Ref.: HAR2014-58043-P, Ministerio de Economía y Competitividad, Gobierno de España.

\section{NOTES}

1 In relation to the presented global estimation, see especially Anne-Marie, Bauer (1993), J. Fleury and M.-S. Binetuy; B. Strebel; Claire Andrieu (2008); http://www.afmd.asso.fr/LesFrancaises-a-Ravensbruck.html. [accessed 01/September/2016]

2 I think of the memories M.-J. Chombart de Lauwe, G. Tillion, G. de Gaulle Antonioz, S. Veil, and many others. Among the essential works, I will remember here: If This is a Man of Primo Levi; Auschwitz and After of Charlotte Delbo (1971). In particular the bibliography on personal reconstruction (or nonreconstruction) after the Holocaust is abundant.

3 Voix et Visages, $\mathrm{N}^{\circ} 1$, June 1946.

4 The Germaine Tillion's Study is based on the International Tracing Services of KL Buchenwald, custodian of the archives of the HASAG Kommando in Leipzig-Schönefeld.

5 Témoignage de Madame Marie-Claude Vaillant-Couturier sur Auschwitz et Ravensbrück. Quarante-quatrième journée. Lundi
28 janvier 1946. International Military Tribunal Nuremberg, http://www.fndirp.asso.fr/wp-content/uploads/2013/03/temoignage_mc_vc nuremberg.pdf. [accessed 01/September/2016]; see also the reports of Vaillant-Couturier and Tillion in the years 1946-1947.

6 Leonor Rubiano Fernández (03/07/1920-09/02/1945) passed through the Women's Prison, Frauenzuchthaus, Cottbus, North of Dresden, where the penalties for forced labor for women are "NN" Transit to Ravensbrück. Email of the Municipal Archives of Mieres (Asturias) of the 16/09/2016: "In the municipal paddle of 1920 apears Leonor Rubiano Fernández, of Rozadas de la Peña, Mieres. Her parents are Germán Rubiano Martínez and María Fernández Fernández and her brothers and sisters Víctor, Quintiliano, Carmen and Justa". Vaillant-Couturier also cites Marie Alonso (Santa Fe de Mondújar, 20/August/ 1910-Auschwitz/27/February/1943) who was a member of the "Réseau des Postiers" ("Postal Network") and who has a plaque at the Tenon Hospital in Paris where she was a nurse: "Dead for France".

7 The only place where Germaine Tillion speaks of the Spanish women deportees but this in a general way: Tillion (1973: 26).

8 The decision to dissolve the ADIR (1945-2005) was taken in March 2005 in order "not to pursue a great and beautiful story which could erode due to lack of combatants".

9 It was only too late, once Franco died, that Ravensbrück's Association took shape. See his genesis online http://www.amicalravensbruck.org/. [accessed 01/September/2016]

10 Between April 1 and May 15, 1945, the guards organized columns of evacuees by roads and railways. It leaves more than 200000, it comes back less than 32000 .

11 Recalled that in 1995, on the sixtieth anniversary of the liberation of the Auschwitz camp, the ICRC regarded this episode as "the greatest failure in its history"; Farré; Schubert: 2009.

12 For an example of negotiation, see Germaine Tillion and Francine de la Gorce: "Geneviève was negotiated between Himmler and the Swiss Red Cross following a Himmler's intervention with the Red Cross so that the latter could send the mail he wanted to send to Eisenhower." http://www.revue-projet.com/ articles/2002-2-itineraire-genevieve-de-gaulle-anthonioz/. [accessed 05/September/2016]

13 Farré specifies: 299 French and one Polish; this would be the Countess Karolina Lanckorońska, author of Michelangelo in Ravensbrück: One Woman's War against the Nazis (2007), Cambridge, Mass., Da Capo. The ICRC keeps: Returnees, photos upon arrival in Switzerland, report by Dr. A. Jost.

14 http://florentinejeansueur.webnode.fr/news/la-liberationde-florentine/.

[Accessed 15/September/2016]

15 In the convoy of the "27000", that of Geneviève de Gaulle (27372), there were at least 5 deportees born in Spain: 27534 Roger Neige; 27181 Kerwich Laure; 27964 Ruiz de Angulo Elisa; 27244 Pérez Rita; 27973 Roques Marie.

16 "Theoretically all 'NN' prisoners (Nacht und Nebel) had left the camp on 2 March for Mauthausen. At the same time that the 'NN' (about 800, I do not have the number present in memory) left Gypsies with their children...'

17 S. Farré refers to columns 35, 36 and 37. The women transferred to Mauthausen obtained, after negotiations between the Red Cross and the RSHA (Reichssicherheitshauptamt), an early release as well as the still valid French, Belgian, Luxembourg and the Netherlands

18 Testimony of Violette Maurice, http://forezhistoire.free.fr/images/23Village-de-Forez-1985.pdf. [accessed 26/September/2016]

19 Http://www.monument-mauthausen.org/spip.php?page=search [accessed 26/September/2016].

20 In these expeditions slip off the officially French Spanish women. Thus would have passed by St. Gall, Segura Montes and Garcia Bayena. In Toute une vie de résistance, Marie-Jo Chombart de Lauwe evokes the surprises of evacuation: "It is said that the Russians are approaching on one side, the Americans on the other. Liberation comes to us. Many camps are retreating on Mauthausen. Women even find their husbands." In fact, we find "Alphonsine" (Bueno) and "Joseph" (Ester), see 
Documents concerning the repatriation of Ester and his wife Alfonsina. 1945-1946 and n.d.: Internationaal Instituut voor Sociale Geschiedenis, Amsterdam, Nederland.

https://search.socialhistory.org/Record/ARCH02428/ ArchiveContentList.

[accessed 01/October/2016]

21 Testimonial Video of 120 min by Koulikoff Martínez in 1996 (BDIC).

22 Feliciana, daughter of Justo Pinto Calvo and Eugenia Navas Muñoz, born on June 9, 1914 in El Barraco (Ávila), married in 1936 to Joseph Raymond Bierge (number 1285), transferred to Mauthausen more than two thousand deportees. See: http://aragonesesexilioydeportacion.blogspot.fr/2012/01/felicianapintos-navas-superviviente-de.html. [accessed 01/October/2016]

23 ADIR offers other places of convalescence, with no fee, in Nice, Chambéry or in the Black Forest.

24 "L'activité du service social", Voix et Visages, $N^{\circ} 1$, June 1946 ; "Nos centres de convalescence en Suisse". Voix et Visages, $\mathrm{N}^{\circ}$ 3, October 1946.

25 "L'activité du service social", art. cit.: 3. In the Report of January 1947 on the "Assemblée Générale", the number of members amounts to 1151 .

26 Farewell to Swiss: Voix et Visages, Nos 3 \& 4, October \& November 1946 (see Sivadon).

27 "Convalescence", Voix et Visages, $\mathrm{N}^{\circ}$ 11-12, February-March 1948: 4-5.

28 Affirmed from 1946, in the first two issues of Voix et Visages, by the General Secretary of ADIR, Claire Davinroy (Davinroy, Claire, 1946a; Davinroy, Claire. 1946b).

29 I summarize here the journey that can be read in Les Françaises à Ravensbrück, op. cit.

30 The third survivor is Jean-Claude Passerat. See AylmerRoubenne (1997).

31 Three times Count F. Bernadotte (he explains in 1945 in $\mathrm{La}$ Fin) meets Himmler, and only three times. And three times in Hohenlychen, in the clinic of Prof. Gebhardt [ex-fellow of Himmler]. The archives of the Swedish Red Cross have preserved "the drawings that Eliane Jeannin-Garreau had made in Ravensbrück, according to Pavillard.

32 Testimony of Béatrix de Toulouse-Lautrec (Toulouse Lautrec, 1991): 25/April/1944 departure from Ravensbrück - 27/ June/1944 arrived in France. In her convoy -she sais- there were a number of aristocrats. Other testimonies in the collective work of the Françaises à Ravensbrück, op. cit.

33 http://www.chrd.lyon.fr/static/chrd/contenu/pdf/pedago/CNRD/ CHRD_CNRD\%202014-2015.pdf. [accessed 01/October/2016]

34 María Beguiristain born in Zarautz (Guipúzcoa) on the 03/12/1907; Interned at Compiègne on 28/04/1943 and at Ravensbrück on 30/04/1944, Number 19425; Released on 23/04/1945.

35 "Convalescence" and "Chronique sociale", Voix et Visages, N ${ }^{\text {os }}$ 11-12, February-March 1948: 4-6.

36 "Retour du Danemark". Voix et Visages, No 3, October 1946: 3.

37 "Notre foyer". Voix et visages, N ${ }^{\circ}$ 4, November 1946: 3. The ADIR reiterates this at the general meeting of December 1946. La Contemporaine ex-BDIC, Delta Rés 797/I, Dossier 13, and Delta Rés 797/IV, Dossier 77, correspondence concerning repatriation by Sweden.

38 "Assemblée générale" (of 15 Dec. 1946). Voix et Visages, № 5 , January 1947: 3-6, p. 3: "We were lucky enough to receive furniture from Switzerland and, by our care, some comrades could be completely refurnished. Thus, for example, we were able to completely rebuild the home of a household whose husband and wife had both been deported". In Voix et Visages, $\mathrm{N}^{\mathrm{0}} 8$, 1947: 2, reference is made to medicines obtained by the Don suisse, elsewhere to a parcel of the Canadian Red Cross, etc.

39 See the works of Aurelio Velázquez Hernández on the Unitarian Service Committee (USC): "La ayuda humanitaria europea en Francia durante la Segunda Guerra Mundial". Conference at Schweizerisches Sozialarchiv Zürich/UNED, 02/09/2016 (work in progress). The City Council of Zürich donated an X-ray machine to the Warsaw hospital in Toulouse, supported by the Unitarian Service.
40 The list of the 50 Spanish convalescents (mostly men), which followed one another from July to September 1947, included Neus Català (July-August 1947) and Mercedes Núñez (AugustSeptember 1947), as well as their future husbands. Two USC representatives, Draper and Jaeger, advocated in June 1948 the arrest of the center of Meillon "under the philo-communist influence of the Amicale of the deportees".

41 Arrested in Spain on 10/11/1939, Mercedes Núñez Targa was transferred to the Ventas Women's Prison (Madrid). Her testimony dates from 1967: Cárcel de Ventas. To resist the prison, she will have recourse to choral singing, comrades' drawing, activities she will perform in Ravensbrück and Hasag-Leipzig Kommando, where she is with the Spanish María Benítez, Mercedes Bernal, Carmen Boatell, María Ferrer, Constanza Martinez, Elisa Ruiz, Marita [Van Aal]. Hospitalized on her return to the Hospital Bichat (Paris), she goes to Carcassonne by sanitary train to testify against René Bach. Http://www.ara.cat/cultura/dones-Ravensbruck-vencen-loblit_0_849515106.html. [accessed 08/09/2016].

42 The original Spanish version dates from 1984 (De la Resistencia a la Deportación. 50 testimonios de mujeres españolas. Adgena, Barcelona).

43 In Spanish Bibliography on the Mauthausen Camp: J. Borràs; M. Fabréguet; E. Pons Prades; B. Bermejo and many others.

\section{REFERENCES}

Amicale de Ravensbrück et Association de déportées et internées de la Résistance (1965) Les Françaises à Ravensbrück. NRF Gallimard, Paris.

Andrieu, Claire (2008) "Réflexions sur la Résistance à travers l'exemple des Françaises à Ravensbrück". Histoire@Politique. Politique, culture, société, $\mathrm{N}^{\circ}$ 5, May-August: 3-63.

Aylmer-Roubenne, Madeleine (1997) J'ai donné la vie dans un camp de la mort. JC Lattès, Paris.

Bauer, Anne-Marie (1993) Les oubliés et les ignorés: Claudine dans la Résistance (récit), Preface Geneviève de Gaulle Anthonioz, Mercure de France, Paris.

Bermejo, Benito; Checa, Sandra (2006) Libro memorial: españoles deportados a los campos nazis 1940-1945. Ministerio de la Cultura, Madrid.

Bernadotte, Comte Folke (1945) La fin. Mes négociations humanitaires en Allemagne au printemps 45 et leurs conséquences politiques, Trad. Madeleine Blanc-Paulsen. Éditions Marguerat, Lausanne.

Català, Neus (1994) Ces Femmes Espagnoles de la Résistance à la Déportation. Témoignages vivants de Barcelone à Ravensbrück, Preface Geneviève de Gaulle Antonioz, Trad. Caroline Langlois. Éditions Tirésias, Paris.

Chombart de Lauwe, Marie-Jo (1998) Toute une vie de résistance. Éditions Graphein-FNDIRP, with the sponsorship of the "Fondation pour la Mémoire de la Déportation", Paris.

Davinroy, Claire (1946a) "Ce que sera notre bulletin". Voix et Visages, $\mathrm{N}^{\circ} 1$, June.

Davinroy, Claire (1946b) "Nos centres de convalescence en Suisse". Voix et Visages, No 2, August-September.

Delbo Charlotte ([1965] 1998) Le Convoi du 24 janvier. Éditions de Minuit, Paris.

Delbo Charlotte (1971) La mesure de nos jours. Auschwitz et après III. Éditions de Minuit, Paris.

Dufayel, Pierre-Emmanuel (2015) Lutetia, 1945: Le retour des déportés.

Fabius, Odette (1986) Un lever de soleil sur le Mecklembourg, Mémoires. Albin Michel, Paris.

Farré, Sébastien (2012) "Le CICR et les détenus des camps de concentration nationaux-socialistes (1942-1945)". Revue internationale de la Croix-Rouge, Sélection Française, Vol. 94/ 4: 191-219.

Farré, Sébastien; Schubert, Yan (2009) 'L'illusion de 1'objectif. Le délégué du CICR Maurice Rossel et les photographies de Theresienstadt". Le Mouvement social, April-June: 65-83.

Farré, Sébastien (2014) Colis de guerre. Secours alimentaire et organisations humanitaires (1914-1947). Presses Universitaires de Rennes, Rennes. 
Favez, Jean-Claude (1988) "Le proche et le lointain. L'accueil et l'asile en Suisse au printemps 1945". Revue Suisse d'Histoire, Vol. 38: 390-402.

Favez, Jean-Claude (1989) "1942: le Comité international de la Croix-Rouge, les déportations et les camps". Vingtième Siècle. Revue d'histoire, $\mathrm{N}^{\circ} 21:$ 45-56.

Fleury, Jacqueline; Binetruy, Marie-Suzanne (1995) "Ravensbrück”. In Manson, Jean dir., Leçons de ténèbres, Résistants et déportés. FNDIR-UnADIF/Perrin, Paris.

Gaulle-Anthonioz Geneviève de (1977) "Introduction à l'assemblée générale de l'ADIR du 26 mars 1977”. Voix et Visages, N 156, March-April.

Gelly, Violaine; Gradvohl, Paul (2013) Charlotte Delbo. Arthème Fayard, Paris.

Koulikoff Martinez, Ángela (1996) Testimonial video (St-DenisBasilique, 15 october, $120 \mathrm{~min}$ ). In Memorias de los republicanos españoles exiliados en Francia, La Contemporaine exBDIC, Series Spanish War (1936-1939)-Exile.

Laffitte, Henri; Bourgeois, Pierre (2009) "La libération et le rapatriement des déportés”. In Wahl, Alfred, L'Allemagne de 1945 à nos jours. A. Colin, Paris: 341-352.

Mezzasalma, Philippe (2003) "L'ADIR, ou une certaine histoire de la déportation des femmes de France". Matériaux pour l'histoire de notre temps, $\mathrm{N}^{\circ}$ 69, January-March: 49-60.

Monnier, Éric; Exchaquet-Monnier, Brigitte (2013) Retour à la vie. L'accueil en Suisse romande d'anciennes déportées françaises de la Résistance (1945-1947). Éditions Alphil, Neuchâtel.
Nuñez Targa, Mercedes (1967) Cárcel de Ventas. Éditions de la Librairie du Globe, Paris.

Núñez Targa, Mercedes (2011) Destinada al crematorio. De Argelès a Ravensbrück: las vivencias de una resistente republicana española. Renacimiento, Sevilla.

Pavillard, Anne-Marie (2008) "Les archives de l'Association des anciennes déportées et internées de la Résistance (ADIR) à la BDIC”. Histoire@Politique, 2, №5.

Roig, Montserrat (1977) Els catalans als camps nazis. Edicions 62, Barcelona.

Sivadon, Jane (1946), “Adieu à la Suisse”. Voix et Visages, № 4, November.

Strebel, Bernhard (2005) Ravensbrück, Un complexe concentrationnaire. Fayard, Paris.

Tillion, Germaine (1947) "Le procès de Ravensbrück. Ce qui se passe à Hambourg". Voix et Visages, $\mathrm{N}^{\circ} 5$, January.

Tillion, Germaine (1973) Ravensbrück. Seuil, Coll. "L'Histoire immédiate", Paris.

Tillion, Germaine, Gorce, Francine de la (2002) "Un itinéraire: Geneviève de Gaulle Anthonioz". Revue Projet, 1 February.

Toulouse Lautrec, Béatrix (de) (1991) J'ai eu vingt ans à Ravensbrück. Librairie Académique Perrin, Paris.

Vaillant-Couturier, Marie-Claude (1946) Mes 27 mois entre Auschwitz et Ravensbrück. Éd. du Mail, Coll. "Grands discours français et internationaux", Paris. 